О. Я. Савченко. - $\quad$ К. : Магістр-S, 1997. - 254 с. б. Савченко О. Я. Дидактика початкової школи / О. Я. Савченко. - К. : Генеза, 1999. - 338 с. 7. Тименко В. П. Сенсомоторна цілісність як ознака дитячої природності / В. П. Тименко // Початкова школа. - 2003. - № 5. - С. 17-19; 2004. - № 1-2. 8. Цукерман Г. Зачем детям учиться вместе ? / Г. Цукерман. - М. : Знание, 1985. - 80 с.

УДК 37.0

Ірина Родименко

\title{
АЛГОРИТМ ОБСТЕЖЕННЯ ДИТИНИ
}

Родименко I. М. Алгоритм обстеження дитини.

У статті представлено узагальнений алгоритм обстеження дитини в ОПМПК для прийняття надійних діагностико-прогностичних рішень. Характеризується процедура психологічного обстеження дитини.

Ключові слова: клінічне обстеження, нейропсихічна діагностика, психопатологічне обстеження, психологічне обстеження.

Родименко И. Н. Алгоритм обследования ребёнка.

В статье представлено обобщающий алгоритм обследования ребёнка в ОПМПК для принятия надёжных диагностико-прогнозных решений. Характеризуется процедура психологического обследования ребёнка.

Ключевые слова: клиническое обследование, нейропсихическая диагностика, психопатологическое оследование, психологическое обследование.

Rodumenko I. M. Algorithm of inspection of child.

The article describes generalized algorithm of inspection of a child in OPMPK for taking reliable diagnostic decisions. The process of psychological inspection of a child is characterized.

Key words clinical inspection, neyropsynologe abnormal, psychology inspection.

Аналізуючи рекомендації щодо порядку і змісту комплексного обстеження дитини в ОПМПК, представлені у працях окремих науковців (В. Астапов, С. Забрамна, Р. Карімова, В. Липа, Б. Пузанов, Л. Шипіцина, Л. Цвєткова та ін.), і порівнюючи ïx із практичним вирішенням цих питань у діяльності Дніпропетровської ОПМПК, пропонуємо розглянути оптимальні варіанти послідовності, змісту і методик (процедур) обстеження дитини, згруповані з урахуванням принципів діагностичної діяльності.

Підстави для оцінки цих варіантів як оптимальних, дає нам їх багаторічна апробація у практиці ДОПМПК, яка здійснювалась цілеспрямовано, пошуковоаналітично, із внесенням відповідних коректив у діяльність, а також експертна оцінка їі результатів.

Mema cmammi- узагальнити алгоритм обстеження дитини в ОПМПК, схарактеризувати процедуру психологічного обстеження дитини.

У таблиці 1. представлено узагальнений алгоритм обстеження дитини в ОПМПК для прийняття надійних діагностико-прогностичних рішень. 


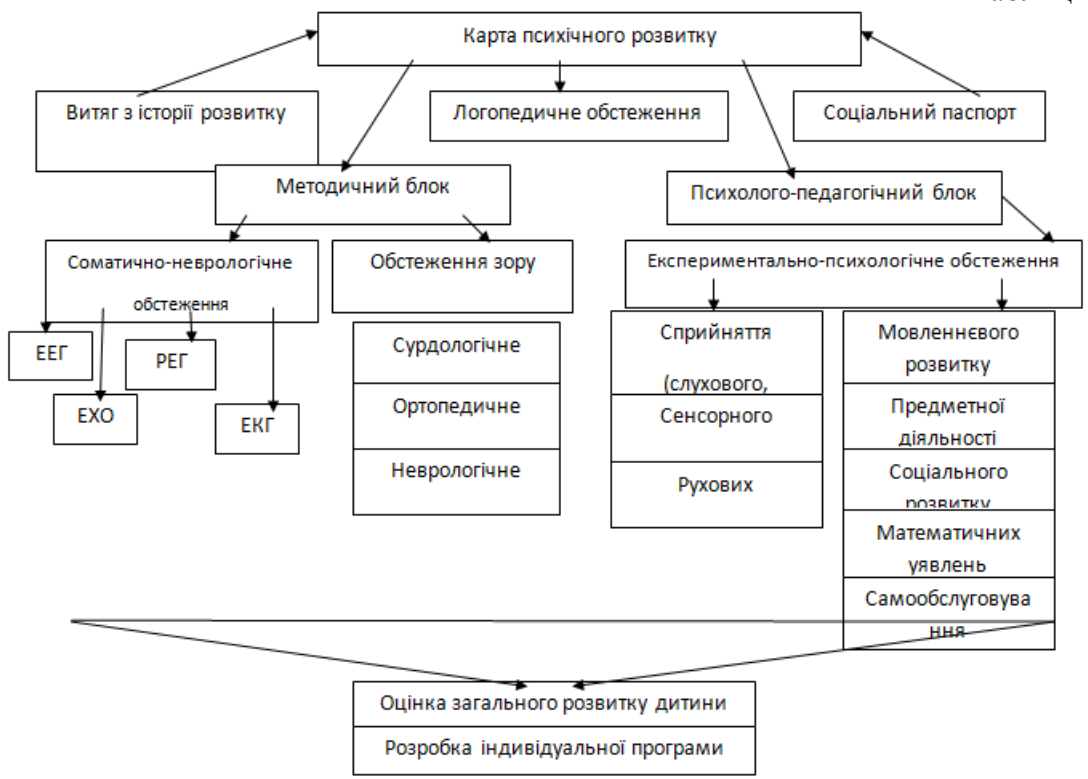

Клінічне обстеження передує психологічному та педагогічному, оскільки дитину направляють на ОПМПК з висновками за попередніми спостереженнями, що засвідчують наявність у неї певних порушень психофізичного розвитку, й первинними гіпотезами щодо факторів, які зумовили ці порушення.

Відтак, клініцист 3'ясовує, які порушення центральної нервової системи органічного або функціонально-динамічного характеру детермінують вади психічної діяльності дитини.

Обгрунтованою є рекомендація щодо проведення клінічного обстеження в два етапи: на першому, за допомогою соматичного, неврологічного, психологопедагогічного, нейропсихологічного та інших досліджень, збираються об'єктивні дані; на другому, отримані результати детально аналізуються, обговорюються та стають підставою для попереднього висновку щодо своєрідності порушення розвитку, його структури.

Нижче наводяться порядок і вимоги до проведення різних видів клінічного обстеження дитини, вказані методики, які дають найбільш показові та надійні результати (наприклад, «Діагностика розвитку дітей раннього віку», розроблена фахівцями ДОПМПЦ; «Методика нейропсихологічної діагностики дітей» Л.С. Цвєткової та ін.).

Доцільно та необхідно використовувати сучасні параклінічні методи неврологічного обстеження: комп'ютерну електроенцефалографію, комп'ютерну ехоенцефалографію, ультразвукову діагностику, комп'ютерну реоенцефалографію.

\section{Педіатричне обстеження.}

1. Мета відвідування.

2. Збір анамнезу:

- спадковість; 
- гінекологічний анамнез матері;

- відомості про психомоторний розвиток;

- перенесені на першому році життя хвороби;

- алергоанамнез;

- перенесені соматичні та інфекційні хвороби;

- щеплення, результати КМ, реакції на щеплення;

- перенесені черепно-мозкові травми;

- хірургічні втручання;

- результати профілактичних оглядів лікарями дитячої поліклініки.

3. Об'єктивне дослідження:

- стан дитини, свідомість, настрій, сон, апетит, контакт з оточуючими;

- стан шкіри та видимих оболонок, вид дермографізму, швидкість його виявлення, стійкість;

- товщина жирової складки, набряки, тургор тканин;

- стан м'язової системи;

- стан лімфатичної системи;

- антропометрія (вага, зріст);

- органи дихання; голос, крик, кашель, перкусія та аускультація легенів;

- серцево-судинна система; перкусія серця, аускультація серця;

- шлунково-кишковий тракт; стан порожнини рота, язика, стан зубів, форма, розміри живота, визначення розмірів печінки, перкусія селезінки;

- сечовидільна система;

- клінічні аналізи.

4. Висновок про стан соматичного здоров 'я дитини містить дані про загальний фізичний стан.

5. Рекомендації та складання плану медичного супроводу: режим, дієта, консультації спеціалістів, рекомендації за методика ми загальнооздоровчих, профілактичних заходів.

\section{Психопатологічне обстеження.}

Найвідповідальніше завдання - встановлення первинного діагнозу психічного стану та динаміки психічного розвитку дитини.

1. Ретельне ознайомлення 3 представленою документацією (психологопедагогічною характеристикою, довідкою з висновками необхідних спеціалістів).

2. Бесіда з батьками, збір анамнестичних даних.

3. Психопатологічне дослідження, подальше співвідношення одержаних даних 3 результатами попередніх (неврологічного, психологічного, педагогічного, логопедичного) обстежень.

4. Аналіз психічного статусу, встановлення діагнозу.

5. Висновок.

6. Розробка рекомендацій та плану психокорекційних заходів.

Окремі психічні функції, ще аналізуються у процесі психопатологічного дослідження

1. Свідомість:

- кількісні порушення (сомноленція, сопор, кома);

- якісні порушення (аментивний синдром, делірій, запаморочення свідомості).

2. Сприйняття:

- кількісні порушення (підвищена чи знижена чутливість до подразників); 
- якісні порушення (аномалії сприйняття, галюцинації, псевдогалюцинації).

3. Орієнтування (у часі, місці, ситуації тощо).

4. Пам’ять (на події минулого, теперішні події, опосередкована та неопосередкована):

- кількісні порушення (ретроградна, психогенна амнезія, поступове ослаблення пам'яті);

- якісні порушення (надумані спогади, фантастична псевдологія, симптоми Degavu (симптом «уже баченого»), Jamaisvu (симптом «ніколи не баченого»), розлад здатності до запам’ятовування (забування).

5. Нахили та активність:

- кількісні порушення (посилення чи зниження потягів);

- якісні порушення (нав 'язливість, компульсивні та імпульсивні дії).

6. Афективна сфера:

- кількісні порушення (підвищена емоційність, афективне виснаження);

- якісні порушення (емоційна лабільність, синдром манії-ейфорії, депресивний синдром).

7. Мислення:

- формальні розлади (затримка мислення, прискорення, розірваність);

- розлади за змістом (нав 'язливі ідеї, марення).

8. Інтелект:

- кількісні розлади: низький рівень інтелектуальних здібнос тей;

- якісні розлади: парціальні порушення інтелекту.

9. Особистість:

- суб'єктивні порушення (зміни в собі відмічає пацієнт);

- об'єктивні порушення (зміни помічають оточуючі).

Остаточний діагноз формулюється психіатрами ОПМПЦ згідно з класифікацією захворювань МКЗ-10.

\section{Соціально-педагогічне обстеження.}

1. Мета відвідування ПМПК (соціально-педагогічні проблеми, труднощі в навчанні, спілкуванні, розлади поведінки, проблеми зі здоров'ям тощо).

2. Ознайомлення 3 документами (акт обстеження житлово-побутових умов проживання сім’ї, медична документація про захворювання дитини, характеристики 3 дитячих закладів, табель успішності тощо).

3. Анкетні дані (прізвище, ім'я, по батькові, рік, дата народження дитини, домашня адреса, телефон):

- назва дитячого закладу, клас, результати навчання, взаємодія сім'ї та школи, допомога дитині в навчанні з боку батьків, інтереси дитини, доручення, відвідування гуртків, найулюбленіші заняття, соціально-педагогічна занедбаність, особистісні особливості, риси характеру, схильності та звички, причини неблагополуччя, позитивні та негативні риси, особливості адаптації, поведінка вдома, у школі, серед ровесників, як негаразди позначаються на поведінці та успішності.

4. Соціальні проблеми (характеристика житлово-побутових умов та матеріальних статків сім’і, санітарний стан помешкання дитини):

- житлові умови (окрема квартира, кімната в комунальній квартирі, гуртожиток; вивчення соціального стану та середовища, в якому виховується дитина, наявність сусідів і взаємини з ними, виникнення проблем та їх залагодження, соціально-правова допомога та захист прав неповнолітніх); батьки);

- матеріальні проблеми (затримка заробітної плати, пенсій, допомоги, безробітні 
- психологічні проблеми (несумісність з батьками, ровесника ми, взаємини в сім ‘ї, ставлення до дитини, неадекватні методи виховання).

5. Вивчення сім’ї (склад родини: повна, неповна, багатодітна, наявність братів і сестер; хто займається вихованням, відсутність батьків, батьки, позбавлені батьківських прав, діти відібрані за рішенням суду, опікуни, усиновлення, батьки-інваліди, засуджені, перебувають у розшуку, ведуть аморальний спосіб життя):

- прізвище, ім'я, по батькові матері, батька, опікуна, усино вителя, фактичного вихователя, прийомних батьків, зв'язок сім'ї 3 освітнім закладом, відповідальне ставлення батьків до дітей;

- місце роботи батьків, їх заробітна плата, пенсії та інші прибутки сім’ї.

6. Обстеження сім'ї вдома (за необхідності).

7. Висновки (враження про дитину, прийняття конкретних заходів щодо соціально-педагогічного захисту, надання допомоги дітям, які потрапили в кризові ситуації, допомога у праце влаштуванні, допомога спеціалістів, захист права на освіту, збереження й зміцнення здоров'я, право на відпочинок, розвиток, педагогічний вплив на поведінку дитини).

8. Необхідність звернення до інших закладів, установ для на дання допомоги дитині та її сім’ї.

Ефективність психологічного обстеження на ПМПК забезпечується використанням відповідних програм вивчення психічного розвитку дитини, методик психодіагностики, призначених для досліджень уваги й сенсомоторних реакцій, сприймання, пам'яті, перебігу процесів мислення та психометричного вивчення інтелекту, 3'ясування особистісних особливостей, опитувальників, проективних тестів тощо. Доцільно застосовувати оригінальні психодіагностичні методики, створені вітчизняними авторами (колектив авторів під керівництвом Н. Стадненко), а також продуктивні зарубіжні процедури діагностики розвитку дитини, зокрема, «Мюнхенську функціональну діагностику розвитку».

Вихідними положеннями при розробці методики Н. Стадненко та колективу науковців було те, що для визначення природи відхилень у розвитку не може виступати рівень знань дитини, рівень розвитку окремих пізнавальних процесів, бо і в нормі іноді спостерігається погана пам'ять, увага та ін. Не може бути показовим i актуальний розвиток дитини (те, що дають окремі тести). Вирішальне значення для оцінки психічного недорозвитку мають дані про резерви розвитку дитини, про іiі здатність 3 допомогою дорослих здобувати знання, користуватися ними, тобто здатність до навчання чи научуваність.

Розроблений комплекс діагностичних завдань спрямований на вивчення складників научуваності, самостійності, гнучкості, стійкості, усвідомленості мислення. Ураховувалося, що ці якості не $є$ незмінними, вони мають сенситивні періоди розвитку, що визначає їх якісні відмінності у дітей різного віку. У цьому комплексі є різні набори методичних завдань. Добір завдань для кожної вікової групи здійснюється 3 урахуванням особливостей психічного розвитку кожного віку у нормі та їх нормативно-вікових досягнень.

У цій методиці, на відміну від традиційних тестів, оцінюється ще кінцевий результат виконання, а сам процес, тобто те, як дитина сприймає завдання, чи утримує його в пам'яті до кінця виконання, е якій формі приймає завдання (вербальній, наочній), чи вміє скористатися допомогою, наскільки практичні дії опосередковані мовою, чи вміє пояснити як діяла.

Для вивчення вищезазначених параметрів методикою передбачено різні форми 
інструкції, міри допомоги, що виступають у методиці об'єктом оцінки. Правильне виконання завдання оцінюється по-різному, залежно від ступеня самостійності. Таке використання балів забезпечує якісно-кількісну характеристику інтелектуального розвитку дитини. Оцінка роботи дитини в балах полегшує використання методики і обмежує довільність в оцінці її стану. Але для якісного дослідження дитини одних балів для виконання завдань недостатньо, необхідна ще характеристика складників діяльності, зокрема таких, як особистісний контакт, інтерес до змісту роботи, способи виконання та праце здатність. Названі параметри тісно пов'язані з інтелектом і май же не залежить від віку дитини. Проте при визначенні діагнозу не можна базуватися лише на характеристиці цих параметрів, бо вони так само як і рівні виконання завдань, пов'язані зі станом дитини не однозначно. Висновки щодо стану дитини $\epsilon$ обгрунтованими тоді, коли зіставляються дані про результати виконання завдань 3 характеристикою якості компонентів діяльності.

Охарактеризуємо процедуру психологічного обстеження дитини, що проводиться з використанням таких методів:

1. Вивчення документації задля отримання анамнестичних даних, відомостей про причини відхилень у розвитку. Основни ми документами є: медичні дані педіатра про загальний стан дитини, психоневролога 3 обгрунтованим медичним діагнозом, отоларинголога, офтальмолога та ін., педагогічна характеристика з дитячого закладу, в якому перебувала дитина до направлення в ОПМПК. Метод вивчення документації дає психологові змогу визначитися щодо напрямів подальшого обстеження дитини.

2. Метод бесіди. У процесі спілкування з батьками, з особами, що належать до мікросоціального оточення дитини, безпосередньо 3 дитиною з'ясовуються особливості ії психічних проявів, розвитку в ранньому та дошкільному віці, ії інтереси, здібності, специфічні риси характеру, поведінки, ставлення до стану власного здоров'я. Бесіда має особливе значення для встановлення контакту з дитиною.

3. Вивчення результатів діяльності дитини. Аналізується кінцевий результат певної діяльності: малюнки, письмові та навчальні роботи тощо. Мета цього методу - збір фактичного матеріалу для вивчення особливостей психічного розвитку дитини. Аналіз результатів дитячої творчості дає змогу виявити особливості уяви, зорових уявлень, розвитку дрібної моторики.

4. Метод спостереження. Психологічне спостереження дає змогу зробити висновки щодо різних проявів психіки дитини в умовах іiі природної діяльності за мінімального втручання 3 боку дорослого. В умовах ПМПК найбільше даних спостереження можна одержати під час роботи в діагностичних i корекційних групах. Результати спостереження за дитиною фіксуються у протоколі, в короткому вигляді вони заносяться до карти психологічного обстеження. Реєстрація спостережень може здійснюватися за допомогою магнітофонного запису, відеомагнітофона (за наявності).

5. Метод тестування. Для порівняльної оцінки рівнів роз витку певних психічних проявів, можливостей, здібностей, розумового розвитку дитини використовуються психодіагностичні методики.

\section{Методики психологічного обстеження}

Методики для обстеження уваги та сенсомоторних реакцій: коректурна проба, рахунок за Крепеліним, знаходження чисел за таблицями Шульте, проби на переключення уваги за допомогою «Червоно-чорної таблиці».

Методики для дослідження пам'яті: тест зорової та слухової пам'яті, проби на запам'ятовування 10 слів, проби на асоціативну пам'ять, метод піктограм.

Методики для дослідження рівня розумових процесів: розуміння оповідань і 
сюжетних малюнків, визначення послідовності дій, класифікація, виключення зайвого, виділення суттєвих ознак, утворення аналогій, розуміння приказок і метафор, по рівняння понять, добір слів-антонімів.

Психометричні методи дослідження інтелекту: методика Векслера, таблиці Равена.

Методики для дослідження особистісних якостей: дослідження самооцінки за методикою Дембо-Рубінштейн, особистісні опитувальники (Айзенк, Кетел, Шмішек, Личко, Баса-Дарки), шкали оцінки тривожності Тейлора, Спілбергера.

Проективні методи дослідження особистості: метод незакінчених речень, «Будинок, дерево, людина», «Неіснуюча тварина», «Малюнок сім’ї», тест Люшера, тест Розенцвейга.

\section{Педагогічне обстежения}

1. Попередня бесіда.

2. Ознайомлення $з$ документацією: характеристика, медичні дані.

3. Бесіда з батьками, або з особами, які їх замінюють (з'ясовуються причини звертання до консультації).

4. Встановлення контакту 3 дитиною, виявлення кругозору, особливостей орієнтації в навколишньому середовищі: Як тебе звати? Назви своє прізвище, побатькові. Скільки тобі років? Коли твій день народження? Яка зараз пора року? Назви всі осінні (літні, зимові, весняні) місяці. Пригадай основні прикмети осені (літа, зими, весни).

Дитина 6-7 років має назвати 6-7 ознак певної пори року. Якщо самостійно не називає - пропонується наочно-образна допомога, сюжетні малюнки, на яких зображені пори року. У випадку, коли цей вид допомоги недостатньо ефективний, дитині пропонується показати пори року на малюнках. Якщо пори року розрізнюєпропонують гру «Добери пору» (до малюнків необхідно дібрати парні 3 відповідної пори року). Це завдання дає змогу перевірити як швидко засвоює дитина знання і вміє використовувати набутий досвід у новій ситуації.

Обстеження знань, умінь, навичок відповідно до програми (дочкільного, икільного) закладу

Математика:

Порівняння предметів за кольором, формою, розміром. Рахунок до... Зворотна лічба. Співвідношення числа і цифри, спосіб виконання дій (прямий, зворотній). Склад числа. Володіння навичками обчислювальних прийомів, використання математичної термінології. Вміння встановлювати логічні зв'язки під час розв’язання простих, складних, типових задач.

Письмо:

- Сформованість аналізу на факторному, морфологічному, синтаксичному рівнях.

- Вміння виділити і пояснити орфограми, сформулювати пра вило, дібрати приклади.

- Робота 3 деформованим текстом.

- Письмо під диктовку: сформованість графічних навичок, характер помилок.

Читання:

- Спосіб читання (побуквене, поскладове, цілими словами, вільне).

- Якість читання (темп, плавність, виразність, усвідомленість).

- Переказ (повний, послідовний, за навідними запитаннями, примітивний, фрагментарний).

- Здатність зробити висновки з урахуванням особливостей тексту (опис, оповідання, міркування).

5. Бесіда з батьками чи особами, які їх замінюють: методичні рекомендації щодо навчання, виховання, корекції. 


\section{Література}

1. Астапов В. М. Введенне в дефектологию с основами нейропатопсихологии / В. М. Астапов. - $\quad$ М. : Международная педагогическая академия, 1994. 2. Забрамная С. Д. Из истории методов выявления умственной отсталости / С. Д. Забрамная. - М. : Просвещение, 1970. - 236 с. 3. Забрамная С. Д. Материалы психолого-педагогического обследования в медико-педагогических комиссиях / С. Д. Забрамная. - М. : Просвещение, 1985. - 218 с. 4. Забрамная С. Д. Отбор умственно отсталых детей в специальные учреждения / С. Д. Забрамная. - М. : Просвещение, 1988. - 113 с. 5. Забрамная С. Д. Указания к работе над курсом «Методы отбора детей во вспомагательную школу»/ С. Д. Забрамная. - М. : Просвещение, 1970. - 78 с. 6. Карімова Р. Б. Науково-методичні основи діагностики й корекції психоневрологічного розвитку дітей дошкільного віку з церебральноорганічною патологією / Р. Б. Карімова / автореф. дис. на здобуття наукового ступеня д-ра психол. наук: Інститут спеціальної педагогіки АПН України. - К., 2002. - 20 с. 7. Липа В. А. Основи корекційної педагогіки / В. А. Липа. - Д. : Лебідь, 2002. - 315 с. 8. Синьов В. М. Специфічні закономірності розвитку психіки у дитини. Діти 3 обмеженими фізичними та розумовими можливостя ми в системі корекційного навчання i виховання / В. М. Синьов. - К. : Вища школа, 1997. - 325 с. 9. Стадненко Н. М. Значение психологического обследования в работе отборочных медико-педагогических комиссии / Н. М. Стадниченко // Дефектология. - 1990. № 2. 10. Стадненко Н. М. Очерки по психологии умственно от сталого ребенка. К. : Рад. шк., 1967. - 128 с. 11. Стадненко Н.М. Проблеми работи медикопедагогических комиссии / Н. М. Стадненко // Дефектология. - 1989. - № 6. 12. Стадненко Н. М. Роль диференціальної діагностики розумо вого розвитку дітей під час розробки стандартів освіти / Н.М. Стадненко // Дефектологія. 2001. - № 3. 13. Стадненко Н. М. Діагностика відхилень в розумовому розвитку учнів. - К. : Освіта, $1993 . \quad$ - 239 с. 14. Шипицына Л. М. Нейропсихологические аспекти диагностики детей в процессе коррекционноразвивиющего обучения / Л. М. Шипицына // Дефектология. - 1995. - № 5. - С. 78-92.

УДК: 159.9:504

Дарія Федоренко

\section{ОСОБЛИВОСТІ ПРОВЕДЕННЯ ФОРМУВАЛЬНОГО ЕКСПЕРИМЕНТУ З ПРОБЛЕМИ ВИХОВАННЯ ЕКОЛОГІЧНОЇ КУЛЬТУРИ СТАРШОКЛАСНИКІВ}

Федоренко Д. О. Особливості проведення формувального експерименту 3 проблеми виховання екологічної культури старшокласників.

У статті представлено результати формувального експерименту 3 проблеми виховання екологічної культури старшокласників. Автор додержується думки про те, що для проведення формувального експерименту зі старшокласниками у загальноосвітній школі необхідним $є$ забезпечення набуття поглибленого рівня екологічної освіти відповідно до спеціалізації, усвідомлення взаємозалежності екології й економіки, знання груп професій за їх впливом на навколишній світ, особливості впливу майбутньої професії на довкілля. У статті розкрито ефективні форми i методи виховання екологічної культури старшокласників - екологопсихологічні тренінги та проблемні методи.

Ключові слова: екологічна культура, учні старшого шкільного віку. 